http://jmscr.igmpublication.org/home/ ISSN (e)-2347-176x ISSN (p) 2455-0450

crossref DOI: https://dx.doi.org/10.18535/jmscr/v9i7.04

Journal Of Medical Science And Clinical Research

IGM Publication

An Official Publication of IGM Publication

\title{
Serum $\gamma$-Glutamyltransferase and Risk of Metabolic Syndrome and Type 2 Diabetes in Indore
}

\author{
Authors \\ Laxminarayan Meena ${ }^{1 *}$, Shreya Nigoskar ${ }^{2}$, Randhir Kumar Pandey ${ }^{3}$, \\ Vandana Mahapatra ${ }^{4}$ \\ ${ }^{1,3}$ Department of Biochemistry, ${ }^{2}$ Department of Biochemistry, ${ }^{4}$ Department of Physiotherapy \\ ${ }^{1,3}$ National Institute of Medical Sciences and Research, Jaipur, Rajasthan \\ ${ }^{2}$ Index Medical College, Indore, M.P. \\ ${ }^{4}$ NIMS College of Physiotherapy, Jaipur, Rajasthan \\ *Corresponding Author \\ Dr Laxminarayan Meena
}

Sr. Demonstrator, Department of Biochemistry, National Institute of Medical Sciences \& Research, Jaipur, Rajasthan, India

\begin{tabular}{l} 
Abstract \\
Background \& Objectives: To investigate the association between serum $\gamma$-glutamyltransferase (GGT) and risk of \\
metabolic syndrome and type 2 diabetes. \\
Methods: This study included 250 metabolic syndrome free men and 250 nondiabetic men aged $35-59$ years who \\
did not have medication for hepatitis, alanine aminotransferase (ALT). We used a customized National Cholesterol \\
Education Program definition of metabolic syndrome with BMI instead of waist border. \\
Results: With alteration for age, family history of diabetes, BMI, alcohol intake, cigarette smoking, regular physical \\
activity (fasting plasma glucose for the risk of type 2 diabetes) the risk of metabolic syndrome and type 2 diabetes \\
increased in association with the levels of serum GGT, ALT, aspartate aminotransferase (AST), and alkaline \\
phosphatase. Additional modification for all of the other liver enzymes attenuated these relations, but serum GGT \\
remained a significant risk factor for the risk of both metabolic syndrome and type 2 diabetes. \\
Conclusion: These results point to that serum GGT may be a significant predictor for increasing metabolic \\
syndrome and type 2 diabetes. \\
Keywords: $\gamma$-glutamyltransferase, Cardiovascular, Aspartate aminotransferase (AST). \\
\hline
\end{tabular}

\section{Introduction}

In accumulation to its analytical uses, serum $\gamma$ glutamyltransferase (GGT) has extensive epidemiologic implication ${ }^{[1]}$. Prospective studies ${ }^{[2,3]}$ have shown a significant association between serum GGT and the progress of specific situation with coronary heart disease (CHD) and stroke. In accumulation to alcohol, obesity has been establish $^{[4]}$ to have a major cause on serum GGT, and there is increasing confirmation ${ }^{[4-8]}$ involving raised serum GGT levels with other metabolic disorder, such as glycemic disorder, hypertension, hypertriglyceridemia, and low HDL cholesterol. Excess evidence of fat in liver, usually termed non alcoholic fatty liver disease, is directly related with high serum GGT, obesity, insulin resistance, and hyperinsulinemia ${ }^{[9-11]}$. The Adult Treatment Panel III of the National Cholesterol Education Program (NCEP) newly proposed a meaning of the metabolic syndrome to aid recognition of individuals at risk for both CHD and type 2 diabetes $^{[12]}$. The meaning incorporates thresholds for five easily calculated variables connected to insulin resistance: waist circumference, 
triglyceride level, HDL cholesterol level, fasting plasma glucose level, and blood pressure. The NCEP-defined metabolic syndrome categorization is triggered when predefined restrictions of any three of these five criteria are exceeded ${ }^{[13-15]}$. BMI has been lately adopted in its place of waist circumference for analyses of metabolic syndrome [16,17]. Using a modified NCEP description with BMI instead of waist circumference, we examined the relationship of serum GGT with metabolic syndrome and type 2 diabetes (as diagnosed with the 1997 revised criteria of the American Diabetes Association $^{[18]}$ for epidemiological studies) in Indian male office workers and performed a longitudinal study to prospectively examine the association of serum GGT with the development of metabolic syndrome and type 2 diabetes. Probable relations between other liver enzymes (aspartate aminotransferase [AST], alanine aminotransferase [ALT], and alkaline phosphatase) and risk of metabolic syndrome and type 2 diabetes were also examined.

\section{Subjects and Method}

Our study is an ongoing cohort investigation, designed to clarify risk factors for major diseases, including hypertension, dyslipidemia, and diabetes, among Indore men who are office workers at one of the biggest building contractors in India. A total of 500 males office workers aged 35-59 years participated in cardiovascular risk surveys in May 2020, with a participation rate of 99.6\%. The Industrial Safety and Health Law in Indore requires the employer to conduct annual health examinations of all employees.

The study was approved by the Index Medical College Ethics Committee and informed consent was obtained from patients.

\section{Statistical Methods}

The $\mathrm{X}^{2}$ test and one-way ANOVA were used to analyze the statistical differences among characteristics of the study participants at enrollment in relation to serum GGT levels. Categories of serum GGT comprised the following quintiles: <16, 16-22, 23-32, 33-53, and $\geq 54$ units $/$. For calculation of incidence density, person- years of follow-up were calculated from the date of enrollment to the date of the first incidence of the development of the metabolic syndrome or type 2 diabetes or the date of follow-up where either was diagnosed.

\section{Result}

Table 1: Relation to serum GGT levels

\begin{tabular}{|l|c|c|c|c|c|c|}
\hline Characteristics & $<16$ & $16-22$ & $23-32$ & $33-53$ & $\geq 54$ & P value \\
\hline Age (years) & $39.4 \pm 0.6$ & $48.2 \pm 0.3$ & $48.0 \pm 0.2$ & $48.0 \pm 0.1$ & $48.7 \pm 6.8$ & $<0.001$ \\
\hline Family history of diabetes & 6.5 & 10.2 & 10.7 & 8.6 & 10.4 & 0.315 \\
\hline BMI (kg/m2) & $21.1 \pm 1.1$ & $24.1 \pm 2.3$ & $24.8 \pm 2.0$ & $25.5 \pm 3.8$ & $25.4 \pm 3.1$ & $<0.001$ \\
\hline Current drinkers & 70 & 82 & 87.6 & 92.4 & 94.5 & $<0.001$ \\
\hline Current smokers & 42.5 & 47.2 & 52.6 & 54.3 & 57.4 & $<0.001$ \\
\hline $\begin{array}{l}\text { Regular physical activity at least once } \\
\text { a week }\end{array}$ & 50.2 & 52.5 & 53.4 & 58.6 & 58 & 0.132 \\
\hline Systolic blood pressure (mmHg) & $121.4 \pm 142$ & $127.2 \pm 14.4$ & $128.8 \pm 14.3$ & $131.2 \pm 16.2$ & $134.5 \pm 16.4$ & $<0.001$ \\
\hline Diastolic blood pressure (mmHg) & $72.4 \pm 10.4$ & $77.3 \pm 10.5$ & $79.4 \pm 10.2$ & $81.1 \pm 10.9$ & $83.5 \pm 10.9$ & $<0.001$ \\
\hline Total cholesterol (mmol/l) & $4.58 \pm 0.70$ & $4.85 \pm 0.72$ & $6.02 \pm 0.79$ & $6.19 \pm 0.84$ & $6.22 \pm 0.98$ & $<0.001$ \\
\hline HDL cholesterol (mmol/l) & $1.52 \pm 0.31$ & $1.49 \pm 0.33$ & $1.47 \pm 0.37$ & $1.48 \pm 0.37$ & $1.51 \pm 0.35$ & 0.035 \\
\hline Triglycerides (mmol/l) & 0.96 & 1.30 & 1.35 & 1.35 & 1.70 & $<0.001$ \\
& $(0.74-0.29)$ & $(0.951 .74)$ & $(1.00-2.04)$ & $(1.00-2.04)$ & $(1.14-2.54)$ & \\
\hline Fasting plasma glucose (mmol/l) & $4.03 \pm 0.72$ & $5.20 \pm 0.60$ & $5.300 \pm 0.98$ & $5.32 \pm 0.96$ & $5.41 \pm 1.11$ & $<0.001$ \\
\hline AST (units/l) & $16(15-20)$ & $20(17-22)$ & $21(17-24)$ & $23(20-27)$ & $28(23-35)$ & $<0.001$ \\
\hline ALT (units/l) & $13(11-17)$ & $18(14-23)$ & $22(16-28)$ & $25(18-33)$ & $32(24-42)$ & $<0.001$ \\
\hline Alkaline phosphatase (units/l) & 162 & 162 & 165 & 165 & 173 & $<0.001$ \\
& & & & & & $<0.001$ \\
\hline Metabolic syndrome & 5.4 & 10.0 & 15.6 & 24.2 & 29.0 & $<2.3$ \\
\hline Type 2 diabetes & 4.2 & 6.8 & 8.0 & 10.5 & 12.3 & $<0.001$ \\
\hline
\end{tabular}


The distinctiveness of the study sample in relation to serum GGT levels are shown in Table 1. Tests for difference in distinctiveness diagonally the five serum GGT level groups were considerable except for family the past of diabetes and regular physical activity. Age, BMI, current drinking, current cigarette smoking, systolic and diastolic blood pressures, total cholesterol, triglyceride, fasting plasma glucose, AST, ALT, and alkaline phosphatase showed a linear trend in relation to serum GGT. The proportion of those who had the metabolic disease and type 2 diabetes also increased in association with an increase in serum GGT. HDL cholesterol showed a U-shaped association with serum GGT.

\section{Discussion}

Our study has several limitations. First, serum GGT during follow-up was not incorporated in the analysis. In this study, serum GGT at study entry was strongly linked with that at the date of diagnosis of metabolic syndrome and type 2 diabetes or at the end of follow-up (Spearman's rank correlation coefficient 0.751 and 0.750 , respectively; $P_{-} 0.001$ for both). This indicates that those who had the higher serum GGT at study entry tended to continue to do so during followup. The observed associations between serum GGT at baseline and the increased risk of metabolic syndrome and type 2 diabetes may thus reflect the effects of serum GGT during a given observation period.

\section{Conclusion}

Our findings, which were obtained from a cohort of middle-aged Indian men, support the conclusion that elevated, although still normal, serum GGT is associated with a higher risk of the metabolic syndrome and type 2 diabetes.

\section{References}

1. Whitfield JB: Gamma-glutamyl transferase. Crit Rev Clin Lab Sci 38:263355,2001
2. Wannamethee G, Ebrahim S, Shaper AG: Gamma-glutamyltransferase: determinants and association with mortality from ischemic heart disease and all causes. Am J Epidemiol 142:699-708, 1995

3. Bots ML, Salonen JT, Elwood PC, Nikitin Y, Freire de Concalves A, Inzitari D, Sivenius J, Trichopoulou A Tuomilehto J, Koudstaal PJ, Grobbee DE: Gammaglutamyltransferase and risk of stroke: the EUROSTROKE project. $J$ Epidemiol Community Health 56 (Suppl. 1):I25-I29, 2002

4. Nilssen O, Førde $\mathrm{OH}$, Brenn $\mathrm{T}$ : The Troms $\varnothing$ Study: distribution and population determinants of gamma glutamyltransferase. Am $J$ Epidemiol 132:318-326, 1990

5. Perry IJ, Wannamethee SG, Shaper AG: Prospective study of serum $\gamma$ glutamyltransferase and risk of NIDDM. Diabetes Care 21:732-737, 1998

6. Rantala AO, Lilja M, Kauma H, Savolainen MJ, Reunanen A, Kesäniemi YA: Gammaglutamyl transpeptidase and the metabolic syndrome. J Intern Med 248:230-238, 2000

7. Nakanishi N, Nishina K, Li W, Sato M, Suzuki K, Tatara K: Serum gammaglutamyltransferase and development of impaired fasting glucose or type 2 diabetes in middle-aged Japanese men. J Intern Med 254:287-295, 2003

8. Lee DH, Jacobs DR Jr, Gross M, Kiefe CI, Roseman J, Lewis CE, Steffes M: Gammaglutamyltransferase is a predictor of incident diabetes and hypertension: the Coronary Artery Risk Development in Young Adults (CARDIA) Study. Clin Chem 49:1358-1366, 2003

9. Marchesini G, Brizi M, Bianchi G, Tomassetti S, Bugianesi E, Lenzi M, McCullough AJ, Natale S, Forlani G, Melchionda N: Nonalcoholic fatty liver 
disease: a feature of the metabolic syndrome. Diabetes 50:1844-1850, 2001

10. G, Forlani G: NASH: from liver diseases to metabolic disorders and back to clinical hepatology. Hepatology 35:497-499, 2002

11. Malnick SD, Beergabel M, Knobler H: Non-alcoholic fatty liver: a common manifestation of a metabolic disorder. QJM 96:699-709, 2003

12. Expert Panel on Detection, Evaluation, and Treatment of High Blood Cholesterol in Adults: Executive Summary of The Third Report of The National Cholesterol Education Program (NCEP) Expert Panel on Detection, Evaluation, and Treatment of High Blood Cholesterol in Adults (Adult Treatment Panel III). JAMA 285:2486-2497, 2001

13. Wei M, Gaskill SP, Haffner SM, Stern MP: Waist circumference as the best predictor of noninsulin dependent diabetes mellitus (NIDDM) compared to body mass index, waist/hip ratio and other anthropometric measurements in Mexican Americans: a 7-year prospective study. Obes Res 5:16-23, 1997

14. Sattar N, Tan CE, Han TS, Forster L, Lean ME, Shepherd J, Packard CJ: Associations of indices of adiposity with atherogenic lipoprotein subfractions. Int J Obes Relat Metab Disord 22:432-439, 1998

15. Stevens J, Couper D, Pankow J, Folsom AR, Duncan BB, Nieto FJ, Jones D, Tyroler HA: Sensitivity and specificity of anthropometrics for the prediction of diabetes in a biracial cohort. Obes Res 9:696-705, 2001

16. Ridker PM, Buring JE, Cook NR, Rifai N: C-reactive protein, the metabolic syndrome, and risk of incident cardiovascular events: an 8-year follow-up of 14,719 initially healthy American women. Circulation 107:391-397, 2003

17. Sattar N, Gaw A, Scherbakova O, Ford I, DS, Haffner SM, Isles C, Macfarlane PW,
Packard CJ, Cobbe SM, Shepherd J: Metabolic syndrome with and without Creactive protein as a predictor of coronary heart disease and diabetes in the West of Scotland Coronary Prevention Study. Circulation 108:414-419, 2003

18. Expert Committee on the Diagnosis and Classification of Diabetes Mellitus: Report of the Expert Committee on the Diagnosis and Classification of Diabetes Mellitus. Diabetes Care 20:1183-1197, 1997

19. Cucuianu M: Serum _-glutamyltransferase and/or serum cholinesterase as markers of the metabolic syndrome (Letter). Diabetes Care 22:1381-1382, 1999

20. Hotamisligil GS: Inflammatory pathways and insulin action. Int $J$ Obes Relat Metab Disord 27 (Suppl. 3):S53-S55, 2003

21. Hsueh WA, Quinones MJ: Role of endothelial dysfunction in insulin resistance. Am J Cardiol 92:10J-17J, 2003

22. van Oostrom AJ, Sijmonsma TP, Verseyden C, Jansen EH, de Koning EJ, Rabelink TJ, Castro Cabezas M: Postprandial recruitment of neutrophils may contribute to endothelial dysfunction. J Lipid Res 44: 576-583, 2003

23. Stark AA: Oxidative metabolism of glutathione by gamma-glutamyl transpeptidase and peroxisome proliferation: the relevance to hepatocarcinogenesis: a hypothesis. Mutagenesis 6:241-245, 1991. 